\title{
RECURSOS DIDÁTICOS COMO COMPLEMENTO AO ENSINO DE BIOLOGIA PARA PROFESSORES COM DEFICIÊNCIA VISU- AL: um estudo de caso ${ }^{1}$
}

\author{
DIDACTIC RESOURCES AS A COMPLEMENT TO THE TEACHING OF BIOLOGY FOR \\ TEACHERS WITH VISUAL IMPAIRMENT: a case study
}

RECURSOS EDUCATIVOS PARA COMPLEMENTAR LA ENSEÑANZA DE LA BIOLOGÍA PARA LOS MAESTROS CON DISCAPACIDAD VISUAL: un estudio de caso

\author{
Andrezza Santos Flores \\ Mestranda em Ensino e Processos Formativos na \\ Universidade Estadual Paulista "Júlio de Mesquita Filho" (UNESP). \\ São Paulo - SP, Brasil. \\ andrezzaflores6@gmail.com
}

Ângela Coletto Morales Escolano Professora Doutora da Universidade Estadual Paulista“Júlio de Mesquita Filho"- Campus de Ilha Solteira. Ilha Solteira - SP, Brasil.

angelacmescolano@gmail.com

Carolina Buso Dornfeld Professora Doutora da Universidade Estadual Paulista "Júlio de Mesquita Filho" - Campus de Ilha Solteira. Ilha Solteira - SP, Brasil. carolina@bio.feis.unesp.br

\begin{abstract}
RESUMO: Com a Constituição Federal de 1988 e as legislações subsequentes, todos os alunos têm o direito de fazer parte de uma escola regular, inclusive aqueles que possuem algum tipo de necessidade especial. Uma dificuldade maior ocorre quando este deficiente é o professor, pois um professor vidente em sala de aula possui vários artifícios para dinamizar sua aula ao contrário de um professor deficiente visual que muitas vezes não possui recursos alternativos como complemento em sua aula. Dessa forma, o presente trabalho teve como objetivo confeccionar e analisar a utilização de recursos didáticos, voltados para o Ensino de Ciências e Biologia (Fotossíntese, Célula Animal e Célula Vegetal), por uma professora deficiente visual responsável pela sala de recursos de uma Escola Pública Estadual no Noroeste Paulista, que leciona para alunos com cegueira total e baixa visão, buscando-se a melhoria dos recursos para que a mesma desenvolva seu trabalho. Sendo assim, foi possível observar mediante a transcrição e análise dos vídeos que a utilização dos materiais foi de extrema importância para o ensino de seus alunos e para a professora que não teve dificuldades para ministrar suas aulas com o material adaptado. $\mathrm{Na}$ opinião da professora, esta é uma de suas prerrogativas, ou seja, adaptar os materiais para melhor entendimento dos alunos deficientes visuais, mas sua deficiência e a falta de suporte dificultam sua atuação em sala de aula. A utilização dos materiais confeccionados para este trabalho, fez com que a professora participante se sentisse com o dever cumprido perante suas aulas.
\end{abstract}

PALAVRAS-CHAVE: Educação Especial. Ensino de Biologia. Materiais Didáticos. Deficiente Visual.

\footnotetext{
${ }^{1} \mathrm{O}$ artigo relata um estudo apresentado na Iniciação Científica, defendido pela primeira autora com orientação da segunda, disponível na biblioteca Universidade Estadual Paulista "Júlio de Mesquita Filho" UNESP, Campus de Ilha Solteira.
}

$\overline{\text { Artigo recebido em maio de } 2017}$

Aprovado em julho de 2017 
ABSTRACT: With the 1988 Federal Constitution and subsequent legislations, all students have the right to be part of a regular school, including those who have some kind of special need. A major difficulty occurs when the deficient is the teacher, as a psychic teacher in the classroom has several tricks to boost your class, unlike a blind teacher who often does not have alternative resources to complement in your class. Thus, this study aimed to make and analyze the use of educational resources, facing the Science and Biology Teaching (Photosynthesis, Animal Cell and Cell Plant) for a visually impaired teacher responsible for the resource room of a Public State School in the northwest of São Paulo state, who teaches for students with low vision and total blindness, seeking to improve the resources for it to develop its work. Thus, it was observed by the transcription and analysis of videos that use of the material was extremely important for the education of their students and herself, who had no trouble to teach their classes with adapted material. According to the professor, this is one of hers prerogatives; in other words, adapt the materials for better understanding of the visually impaired students, but her disability and lack of support hinders their performance in the classroom. The use of materials made for this work, made the participating teacher feel with fulfilled duty to the teacher's lessons.

KEYWORDS: Special Education. Biology Education. Teaching Materials. Disability visual.

RESUMEN: Con la Constitución Federal de 1988 y la legislación posterior, todos los estudiantes tienen el derecho de formar parte de una escuela regular, incluso aquellos que poseen algún tipo de necesidad especial. La mayor dificultad ocurre cuando este deficiente es el profesor, puesto que un profesor vidente en salón de clase posee varios artificios para dinamizar su clase, al contrario de un profesor con discapacidad visual que muchas veces no posee recursos alternativos como complemento en su salón de clase. De esta forma, el presente trabajo tuvo como objetivo confeccionar y analizar la utilización de recurso didácticos, enfocados para la enseñanza de Ciencias y Biología (Fotosíntesis, Célula Animal e Célula Vegetal), por una profesora con discapacidad visual responsable por la sala de recursos de una Escuela Publica Estadual en el noreste Paulista, que enseña para estudiantes con ceguera total e baja visión, buscándose la mejoría de los recursos para que la misma desenvuelva su trabajo. Siendo así, fue posible observar mediante la transición y análisis de los videos que la utilización de los materiales fue de extrema importancia para la enseñanza de sus estudiantes y para la profesora que no tuvo dificultad para enseñar su clase con el material adaptado. En la opinión de la profesora, esta es una de sus prerrogativas, o sea, adaptar los materiales para mejor entendimiento de los estudiantes con discapacidad visual, pero su incapacidad y la falta de apoyo dificulta su desempeño en el aula. La utilización de los materiales confeccionados para este trabajo, hizo que la profesora participante se sintiese con el deber cumplido ante sus clases.

PALABRAS CLAVE: Educación Especial. Educación Biología. Materiales de Enseñanza. Deficiente Visual. 


\section{1| INTRODUÇÃO}

Nas últimas décadas, e mais especificamente, a partir da Declaração de Salamanca em 1994, a inclusão escolar de crianças com necessidades especiais no ensino regular tem sido tema de pesquisas e de eventos científicos. Esta declaração defende o compromisso que a escola deve assumir de educar cada estudante, contemplando a pedagogia da diversidade, pois todos os alunos deverão estar inseridos na escola regular, inclusive aqueles que possuem algum tipo de necessidade especial (SANT'ANA, 2005; LACERDA, 2006; BRASIL, 1994).

Mesmo a Declaração de Salamanca, sendo reconhecida como marco na Educação Inclusiva, em 1988 os direitos das pessoas com necessidades especiais já eram garantidos pela Constituição Federal Brasileira. Estes direitos estão evidenciados no art. 205 estabelecendo que: "A educação, direito de todos, é dever do estado e da família será promovida e incentivada com colaboração da sociedade, visando ao pleno desenvolvimento da pessoa, seu preparo para o exercício da cidadania e sua qualificação para o trabalho" (BRASIL, 2016).

Já Mendes (2006) destaca que além da Constituição Federal de 1988, a Lei de Diretrizes e Bases da Educação Nacional (LDB) $n^{\circ}$ 9.394/96 estabelece que a educação é um direito de todas as pessoas com necessidades especiais, principalmente na rede regular de ensino, garantindo Atendimento Educacional Especializado (AEE) aos deficientes. Em contrapartida, a legislação ao mesmo tempo em que dá suporte para a possibilidade de acesso à escola comum, não define a obrigatoriedade e até admite a possibilidade de escolarização que não seja na escola regular (BRASIL, 1994, 2016, 1996).

No ponto de vista de Lacerda (2006), a inclusão escolar é vista como um processo gradativo, que pode tomar formas diversas em relação às necessidades dos alunos, já que se pressupõe que a inclusão possibilite o aprendizado de conteúdos acadêmicos e de uso social da leitura e da escrita, sendo o professor mediador e incentivador na construção do conhecimento por meio da interação com ele e com os colegas.

A inclusão escolar é uma proposta dominante na Educação Especial e na Educação em geral nas últimas décadas, incluindo o Brasil, visto que é de extrema importância à transformação da escola, entretanto, há também a necessidade da elaboração de um novo modelo educacional (ENUMO, 2005).

Segundo Silva (2009), existe a necessidade de se pensar em um novo modelo educacional para que todos sejam incluídos de acordo com suas especificidades, então essa ruptura vai além da utilização de materiais didáticos, pois é necessário que os educadores sejam capacitados para atender de forma abrangente a diversidade populacional presente na escola.

Ferreira e Dickman (2015), também destacam que a falta de formação do professor no que se refere ao trabalho com esses estudantes, adicionada a outras situações comuns na rotina docente interferem nesse processo, como por exemplo, violência, baixa remuneração, indisciplina e avaliações institucionais. Entretanto, a maneira pela qual os estudantes são incluídos, está atrelada com a ausência de materiais didáticos que são essenciais para auxiliar no desenvolvimento da relação professor-aluno e aluno-conteúdo. Esta situação desencadeia um processo de assimilação mínima do que deve ser aprendido, além de não permitir o acompanhamento do conteúdo em relação aos outros estudantes.

Sant'Ana (2005) argumenta que a educação inclusiva implica em um ensino adaptado às diferenças e às necessidades individuais, no qual os educadores precisam estar habilitados para atuar de forma competente junto aos alunos inseridos, porém um dos maiores problemas encontrados nessa área é a falta de capacitação dos professores. Assim como citado no trabalho de Pletsch (2009), no qual se destacam diversos estudos que reafirmam a necessidade da melhoria 
da formação de professores, sendo esta uma condição essencial para tornar eficaz a inclusão de alunos com necessidades especiais em rede regular de ensino. Diante desse quadro, é de extrema importância que os professores sejam instrumentalizados a fim de atender as necessidades apresentadas pelos alunos, pois a falta de formação gera sérias consequências para efetivação do ensino inclusivo.

Além disso, há uma grande necessidade de que as escolas estejam preparadas para recebê-las, assim sendo, a escola tem que ser o reflexo da vida do lado de fora. A inclusão possibilita aos que são discriminados, seja pela deficiência, classe social, entre outros fatores que, todos possuam os mesmos direitos e que não podem ter uma vida cidadã pela metade. Porém, outros meios têm como objetivo incluir estes alunos nas escolas, tal como, o AEE, que minimiza as barreiras para a plena participação dos alunos que possuam alguma deficiência, visando a sua autonomia na escola e fora dela. Tendo como função, o atendimento para o ensino especial; porém não podendo ser confundido com reforço escolar (MANTOAN; PRIETO, 2006; MANTOAN, 2011).

No Brasil, em relação às crianças especiais, as propostas para as mudanças estão previstas em lei, entretanto é necessário questionar, assim como o faz Mendes (2006): “Qual a prática necessária? E o conhecimento necessário para fundamentar a prática? É necessário que se faça uma pesquisa mais engajada e que tenham aplicações práticas e políticas mais claras".

Por outro lado, várias aplicações práticas já estão sendo realizadas como no Instituto Benjamin Constant (IBC), que é caracterizado por desenvolver métodos alternativos, assim como, " $A$ célula ao alcance das mãos", vários temas de Biologia foram abordados com a confecção de peças feitas de gesso, facilitando as aulas ministradas e assistidas pelos deficientes visuais da instituição, tendo sempre como preocupação deixar os modelos mais próximos da realidade, com riqueza de detalhes para possibilitar uma aprendizagem efetiva (JORGE, 2010).

Já, o Departamento de Educação Especial da Faculdade de Filosofia e Ciências da UNESP de Marília também desenvolveu um projeto nessa área tendo como título "Processo de inclusão de alunos deficientes visuais na rede regular de ensino: confecção e utilização de recursos didáticos adaptados", sendo que estes recursos foram construídos pelos próprios professores da escola pública, com a orientação dos pesquisadores (OLIVEIRA; BIZ; FREIRE, 2002).

Outra questão, em relação à situação das pessoas deficientes, são os grandes obstáculos encontrados para sua aceitação no mercado de trabalho e na sociedade como um todo. Uma das justificativas é a globalização que tem como objetivo a produtividade com um baixo custo, exigindo trabalhadores cada vez mais capacitados profissionalmente, dificultando ainda mais o acesso desta população ao mercado de trabalho que não encontra uma formação adequada por não serem respeitadas as diversidades de capacidades (ARAUJO; SCHMIDT, 2006).

Destarte, em meio a todos estes problemas enfrentados pelos deficientes, em específico pelo deficiente visual, o presente trabalho teve como objetivo confeccionar e analisar a utilização de recursos didáticos, voltados para o Ensino de Biologia, por uma professora deficiente visual responsável pela sala de recursos de uma Escola Pública Estadual no Noroeste Paulista, buscando-se a melhoria dos recursos para que a mesma desenvolva seu trabalho. 


\section{2 | MATERIAIS E PROCEDIMENTOS}

\subsection{Participante da pesquisa}

A participante é uma professora de 44 anos de idade, deficiente visual há 20 anos, devido a Retinose Pigmentar. É formada em Letras e Pedagogia, sendo especialista na área de Deficiência Visual e na área de Deficiência Mental e Múltipla. Atualmente, leciona em uma Escola Pública Estadual no Noroeste Paulista em uma sala de recursos na área de deficiência visual.

A sala de recursos para deficientes onde a professora atua conta com alunos do Ensino Fundamental II, Ensino Médio e Educação de Jovens e Adultos (EJA), com variações quanto à deficiência, indo desde baixa visão a cegueira total. Assim, o objetivo da sala de recursos é dar ferramentas para que eles possam acompanhar melhor o ensino regular.

Caracterizando os tipos de deficiência visual citados acima, tem-se de acordo com o Ministério da Educação que as pessoas com baixa visão apresentam desde condições de indicar projeção de luz até o grau em que a redução da acuidade visual interfere ou limita seu desempenho, já a cegueira total é a perda total da visão até a ausência de projeção de luz. Assim sendo, a perda da função visual pode ser em nível severo, moderado ou leve, podendo ser influenciada também por fatores ambientais inadequados (BRASIL, 2001).

É importante salientar que alguns alunos são de cidades próximas, dessa forma, frequentam as aulas com o auxílio-transporte disponibilizado pela prefeitura de suas respectivas cidades. As aulas são ministradas no horário inverso às aulas regulares dos alunos.

A participante atua juntamente com as professoras, que pedem para a mesma auxiliar os alunos a desenvolver as atividades que foram aplicadas em sala de aula, assim a professora passa as atividades para o braille, tirando as dúvidas dos alunos. Ensina também a utilizar o soroban (matemática) e até mesmo o computador. Além disso, faz parte da prática pedagógica da participante trabalhar com atividades de Vida Autônoma e Social, como: amarrar o tênis, abotoar a camisa, fechar um zíper, como usar corretamente a bengala entre outras atividades que confere autonomia ao aluno.

Até 2013, a professora atendia os alunos em grupo e várias vezes na semana, mas depois da Resolução 61 de 11 de novembro de 2014, que dispõe sobre a Educação Especial nas unidades escolares da Rede Estadual de Ensino (SP), passou a atender os alunos separadamente, ou seja, em sessões individuais de duas horas, duas vezes por semana, pois cada um tem a sua especificidade (SÃO PAULO, 2014). Dessa forma, a aula na sala de recursos deve ser diferenciada da sala comum, porque na sala regular eles vão aprender o mesmo conteúdo que os demais alunos, mas na sala de recursos o ensino é voltado para as necessidades de cada um.

\subsection{Materiais}

Para a confecção dos recursos didáticos diferenciados foram utilizados os seguintes materiais: massa para Biscuit; tinta plástica Acrilex (coloridas); isopor retangular; isopor redondo (22 $\mathrm{cm})$; cola quente; pistola de cola quente; cola gliter; papel cartão; algodão; lixa; barbante; papel camurça; etileno acetato de vinila (EVA). Para a filmagem foi utilizada uma filmadora JVC.

\subsection{Procedimentos}

O referencial que foi utilizado na presente investigação é de cunho qualitativo, e como destacam Bogdan e Biklen (1994): a origem direta de dados é o ambiente natural e o pesquisador é o instru- 
mento principal de constituição dos mesmos; a pesquisa qualitativa é descritiva; o pesquisador dá ênfase aos processos em relação aos produtos; preocupa-se em entender o significado que os participantes atribuem às suas experiências.

Segundo o procedimento de coleta, a pesquisa foi caracterizada como um estudo de caso, sendo uma pesquisa que privilegia um caso particular, considerada suficiente para análise de um fenômeno, tornando possível uma abordagem minuciosa de uma experiência podendo até mesmo, colaborar nas tomadas de decisões sobre o problema estudado, incluindo as possibilidades de modificações (GONSALVES, 2001).

Assim, de acordo com os procedimentos, primeiramente foi feito o levantamento de temas juntamente com a professora com o objetivo de averiguar os assuntos de Biologia que são tratados em sala de aula. Com isso, levantamos como tema fotossíntese, célula vegetal e célula animal.

Em seguida, os recursos didáticos foram confeccionados, levando em consideração critérios essenciais para atender a deficiência da docente e consequentemente a deficiência dos alunos. Para que isso ocorresse de uma maneira efetiva foi necessário, no momento da confecção, utilizar materiais que visassem uma percepção tátil.

Dessa forma, a fotossíntese foi confeccionada com texturas ásperas e macias, tais como, as raízes da planta com barbante, o gás oxigênio com algodão, gás carbônico com lixa, as folhas com papel camurça, e as demais estruturas com EVA. O manual contém o que é fotossíntese e como ocorre o processo, objetivo do material, que materiais foram utilizados para confecção, instruções de uso e a descrição de todas as estruturas.

Com relação à célula vegetal e animal, utilizamos isopor, tinta plástica e massa de biscuit para dar formato às organelas. Ambos os manuais contém, o que é célula, quais as organelas que as compõe e suas definições, objetivo da maquete, como foram confeccionadas e instruções de uso.

Além disso, os três materiais foram apresentados com a escrita cursiva e em braille. A impressão dos conteúdos em braille foi realizado no Laboratório de Pesquisa e Estudos em Ensino de Ciências e Inclusão Escolar (LEPENCINE) do Prof. Dr. Eder Pires de Camargo.

Finalizada a confecção, os materiais foram testados pela professora participante do projeto, com o objetivo de observar se alterações e ajustes deveriam ser realizados antes de serem utilizados em sala de aula. Assim, vale a pena salientar, que após este teste realizado pela professora, não foi necessário nenhuma alteração nos materiais e nos manuais.

Em seguida, a professora selecionou os alunos que iriam participar da aplicação da aula com o auxílio dos materiais adaptados, de acordo com o ano que o aluno estava cursando. Os alunos selecionados foram: TVP que cursava $6^{\circ}$ ano do Ensino Fundamental; LAN, $1^{\circ}$ ano do Ensino Médio; MMC e WCO, cursavam $9^{\circ}$ ano do Ensino Fundamental.

A coleta de dados foi totalmente filmada e ocorreu por meio de entrevistas e observações, em seguida, os vídeos foram transcritos e analisados.

\section{3| RESULTADOS}

\subsection{Avaliação dos materiais e dos manuais em Braille}

A participante executou o mesmo procedimento de avaliação dos manuais para todos os materiais. Fez a leitura, por meio do computador, pelo programa NVDA (Non visual desktop access - que faz a leitura da tela do computador para deficientes visuais), e posteriormente, avaliou os manuais em braille, destacando que não haveria necessidade de ajustes. 
Em suma, não somente a professora deficiente visual poderá utilizar o material, mas também as professoras do ensino regular, pois o material e o manual são apresentados na forma cursiva, além do braille.

\subsubsection{Avaliação do Recurso Didático para complemento do Ensino de Fotossíntese}

Inicialmente, a seguinte frase da professora destaca que não houve necessidades de ajustes no manual: "O manual está muito bom, pois você fez em braille, sendo uma preocupação muito peculiar, e eu quero te elogiar pela iniciativa, porque eu sou professora a mais de vinte anos e como professora deficiente visual, estou atuando há quinze anos e realmente eu vejo que as pessoas são até sensíveis, mas nós fazemos reuniões pedagógicas e muitas vezes eu participo de seminários, aí as pessoas lamentam, pelo fato de não ter material em braille e pedem desculpas".

Com relação ao teste do material, foi observado que a professora manuseava o material identificando todas as estruturas e elementos que fazem parte do processo da fotossíntese, não deixando aparente nenhuma dificuldade. Segundo a professora, a legenda presente no material também a auxiliou para entender a função de cada elemento que compõe o processo, além disso, a mesma destacou que o tamanho do material estava adequado.

Por fim, a docente finalizou o teste do material coma seguinte fala: "Muito boa esta iniciativa, porque a gente vê que o livro didático do Estado não tem essa preocupação, pois é tudo descrito em desenhos, e o aluno deficiente visual não tem acesso, somente o aluno vidente que vaivercomo que érealizada a fotossíntese, e para o aluno deficiente visual fica vago porque ele não tem a visão do desenho".

Deste modo a participante enfatiza a não preocupação na formulação do material didático do ensino regular em atender a grande diversidade dos alunos, principalmente os deficientes visuais.

\subsubsection{Avaliação do Recurso Didático para complemento do Ensino de Célula Vegetal}

Primeiramente, ao iniciar o teste do material a professora participante logo identificou a forma da célula vegetal. Em seguida, começou a analisar a legenda, para diferenciar uma organela da outra de acordo com as diferentes formas presentes. No entanto, no decorrer deste processo, a professora teve dificuldade com a leitura do nome de algumas organelas, devido à sua complexidade e pelo fato de não ser professora da área de Ciências e Biologia, mas esta dificuldade não a atrapaIhou ao longo do teste, visto que soube muito bem trabalhar com o material, explorando a legenda com as organelas em miniaturas para depois conhecer as organelas na célula como um todo.

Ao finalizar o teste, a fala da professora deixa evidente a falta de preocupação com o ensino para os deficientes visuais, na seguinte frase: "Na geografia, ainda tem alguns materiais adaptados, mas na Biologia eu nunca encontrei, o seu é o primeiro, e isso é muito inovador para a educação, porque a gente sabe que essas células existem, mas nunca exploramos. Os desenhos dos livros, são desenhos a tinta, dessa maneira, não tem como imaginar".

Porém, mesmo a professora tendo acesso a materiais adaptados voltados para geografia, Carmo (2009), destaca que os materiais disponíveis para pessoas com deficiência visual ainda são muito escassos e a falta destes materiais tem comprometido o ensino de conceitos espaciais, da Cartografia e da Geografia para alunos com deficiência visual.

Assim, fica nítida a falta de iniciativa dos profissionais em diversas áreas, porém na área de Ciências Biológicas, a professora deixa esta situação explícita na seguinte frase: "Biologia é uma área que realmente não há essa preocupação de trabalhar com formas inclusivas, para um deficiente visual. Achei muito interessante sua iniciativa, porque a gente sabe que tem célula animal e vegetal e que tem uma diferença, mas a gente nunca explorou esta diferença". 


\subsubsection{Avaliação do Recurso Didático para complemento do Ensino de Célula Animal}

Ao testar a maquete, logo no início do teste, a docente percebeu que o formato da célula animal é diferente da célula vegetal, e não apresentou nenhuma dificuldade com relação à identificação das organelas, tanto que a professora terminou a avaliação do material com a seguinte frase: "Seu material vai ser de suma importância e vai contribuir muito pra que a Biologia seja realmente uma área inclusiva, porque na Biologia tem estruturas internas, e é muito abstrato pra gente que não enxerga o mundo e eu consegui visualizar no concreto, então eu acho que é isso que falta. Não é qualquer professor que se dispõe a fazer um estudo científico tão importante".

Maia, Monteiro e Menezes (2008) reafirma a frase citada acima pela professora, relatando que uma das dificuldades mais apontadas no ensino de Biologia, é o fato de ser amplamente inserido no mundo microscópico, o que dificulta a compreensão do estudante de modo geral.

Esta dificuldade está presente, principalmente, nos conteúdos ministrados sobre Citologia, e o presente trabalho tomou como base a confecção de materiais voltados para este tema, porque apenas os videntes podem ter acesso ao uso do microscópio. Assim, com relação a esta abordagem Pires e Jorge (2014), apontam que a citologia e genética exigem grande capacidade de abstração por parte dos alunos, com isso, é necessário levar em consideração a eficácia de modelos tridimensionais que podem contribuir com o ensino-aprendizagem, principalmente dos alunos deficientes visuais. Deste modo, é evidente a falta de materiais adaptados na área de Biologia, no entanto, o mesmo facilita o entendimento desses conteúdos tanto para alunos quanto para professores.

\subsection{Análise da utilização dos materiais pela professora em sala de aula}

Antes de ministrar as aulas, a professora fazia a leitura do manual no programa NVDA (Non visual desktop access), lembrando que as aulas eram ministradas individualmente, pois cada aluno tem seu horário reservado durante a semana com a professora, por outro lado, a metodologia de ensino utilizada foi a mesma.

\subsubsection{Análise da utilização do material para o Ensino de Fotossíntese}

Para aplicação dos materiais, a própria professora selecionou os alunos na qual ela iria ministrar a aula, levando em consideração as séries que os alunos estavam cursando. Dessa forma, a aula de fotossíntese foi ministrada para dois alunos (TVP e LAN).

$\mathrm{Na}$ aula com a TVP, a professora iniciou apresentando à aluna todos os elementos que são necessários para que ocorra o processo da fotossíntese e exploraram o material em conjunto, ficando explícito na seguinte frase da professora: "O sol é um processo importante. Pra que a fotossíntese aconteça precisa do sol, o sol vem com os seus raios e ele manda luz pra plantinha, a plantinha, através das raízes, absorve as gotinhas de água e essas gotinhas de água são enviadas para o caule e através dos raios solares ocorre a fotossíntese".

Com o aluno LAN, a professora utilizou a mesma metodologia. $E$ ao final de cada aula pediu que os alunos TVP e LAN identificassem alguns elementos que fazem parte da fotossíntese tais como, o sol, os raios solares, as raízes, as gotinhas de água, dentre outros. Dessa maneira, ficou visível que os alunos entenderam o processo, pois eles identificaram todos os componentes solicitados.

Na Fotografia 1, temos o exemplo de utilização do material sobre fotossíntese, onde a professora orienta os alunos a identificar as etapas do processo. 
Fotografia 1 - Professora utilizando o material para ministrar aula sobre fotossíntese

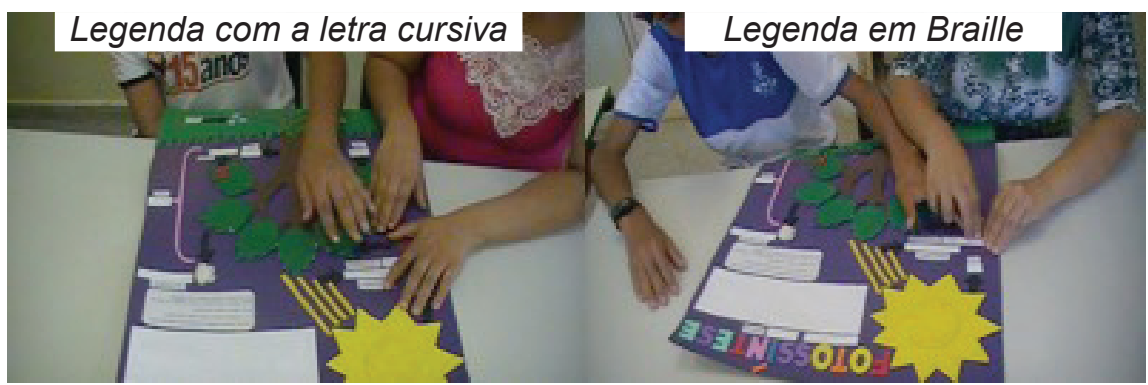

Fonte: Elaborado pelas autoras.

\subsubsection{Análise da utilização do material para o Ensino de Célula Vegetal}

Para ministrar a aula sobre célula vegetal, a professora escolheu três alunos (MMC, LAM e WCO).

Ao iniciar a aula, a professora mostrava, por meio da legenda do material, as organelas para a aluna (MMC), descrevendo todas as suas funções, em seguida a aluna procurava a organela dentro da célula para concretizar seu entendimento com relação à forma, dizendo até mesmo a quantidade de determinada organela que tem no material.

Assim, a professora abordava também a diferença dos formatos para facilitar o entendimento da aluna, e como esta tem baixa visão ela conseguia diferenciar as cores, assim a professora disse: "Muito bem minha aluna, isso é uma informação extra, as cores, pois você tem baixa visão e você viu que a Andrezza foi muito sensível. Porque ela pegou a nossa necessidade na essência, ela pegou a necessidade do deficiente visual total, que é o cego propriamente dito, concretizando tudo pra gente sentir e ela usou um material colorido para que o baixa visão consiga distinguir. Então, por exemplo, se ela usasse tudo de uma cor ia ficar difícil de você ver aqui dentro não é? Então ela pensou nas duas modalidades da deficiência, tanto na cegueira quanto na baixa visão".

É nítido que no decorrer de todas as aulas, a professora utilizava argumentos para destacar a importância dos materiais, tanto para si, quanto para seus alunos. Com esta aluna em especial, foi observado que a professora não foi tão requisitada para a exploração do material, pois esta conseguia identificar as organelas visualizando cores e algumas formas.

Com o aluno LAM, a professora utilizou a mesma metodologia, porém ao explorar o material disse ao aluno: "LAM não é legal você saber o concreto? Porque a célula é microscópica, ela é bem pequenininha, mesmo uma pessoa vidente que enxerga normal, ela só vai ver a célula no microscópio e a gente está tendo o privilégio de manusear".

Batistetil et al. (2009) destaca a necessidade da criação de modelos didáticos para representação de estruturas microscópicas, visto que a abordagem do recurso didático é apenas a partir da utilização de representações. Devido a isso, se torna necessário a utilização de modelos táteis para compreensão do abstrato, contribuindo para o aprendizado dos deficientes visuais e até mesmo dos videntes que mesmo tendo acesso ao microscópio não conseguem distinguir o que enxergam.

Assim, é necessário levar em consideração que, desde a seleção dos conteúdos para confecção dos materiais, a professora destacou os conteúdos no qual ela tem mais dificuldade, pelo fato de serem considerados abstratos pelos deficientes visuais. Com isso, a professora destaca que está sabendo utilizar o material no seguinte trecho: "Pra mim ele está bem no meu recurso mesmo. Eu estou conseguindo explicar bem, mostrar as estruturas, diferenciar, estar mostrando pra eles, e está me dando condições de fazer, porque uma das minhas prerrogativas como professora é estar buscando um material adaptado para o aluno, isso faz parte de promover um curriculo adaptado do Estado de São Paulo, e eu como professora deficiente visual não tenho essa oportunidade 
e com sua ajuda eu consegui realizar uma das minhas funções, e isso me deixa muito feliz".

Já a aula de Célula Vegetal ministrada para o terceiro aluno (WCO) foi um pouco diferenciada, pois o aluno é desinibido e não deixava nem a professora explorar o material, mas a mesma explicou todas as funções das organelas e em seguida, a professora destacou o motivo dessa diferença em uma das suas falas: "O WCO já nasceu deficiente visual e já foi alfabetizado com o braille, ele está no último estágio de aprendizagem, diferente do LAM que ainda está aprendendo o braille separado (sílabas)".

No final de cada aula, a professora pedia para cada um dos alunos identificarem algumas organelas, com o objetivo de averiguar se a aprendizagem tinha ocorrido.

Na Fotografia 2, seguem alguns exemplos de como a professora orientou o manuseio do material com seus alunos e também destaca a legenda em braille e letra cursiva.

Fotografia 2 - Professora utilizando o material para ministrar aula sobre célula vegetal

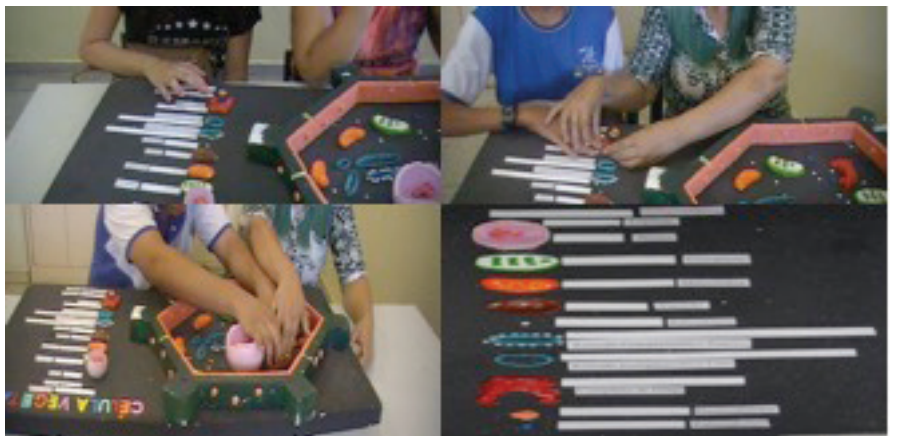

Fonte: Elaborado pelas autoras.

\subsubsection{Análise da utilização do material para o ensino de Célula Animal}

A professora ministrou a aula sobre célula animal para dois alunos, uma com baixa visão (MMC) e outro com cegueira total (WCO), ministrando a aula primeiramente para a aluna MMC.

A professora adotou a mesma metodologia utilizada no material anterior para ministrar o conteúdo, apresentando todas as organelas, destacando suas funções e, mostrou para a aluna a organela dentro da própria célula. Ao tocar as mesmas organelas presentes na célula vegetal, a professora lembrava a aluna da semelhança com a célula animal, destacando que sendo a mesma organela, mesmo estando em células diferentes têm a mesma função.

Vale a pena ressaltar que a professora também fazia associações com o formato, como por exemplo, os microtúbulos que têm o formato de uma "cobrinha", dizendo: "Esta organela é especifica na célula animal [...]". "E o centríolo tem na célula vegetal?”, perguntou a professora, e a aluna respondeu: "Não".

Para finalizar, a professora pediu para a MMC fechar os olhos, pois a mesma tem baixa visão, para identificar algumas organelas dentro da célula, sendo assim, a aluna encontrou todas as organelas que foram pedidas concretizando toda a aula ministrada.

Com relação ao aluno WCO, ao ter contato com a célula animal, ele começou a explorar e disse: "Já achei uma organela que tem na célula vegetal, o núcleo". Devido a essa frase, pode-se destacar que a professora soube explicar o conteúdo por meio do material, pois o aluno já fez comparações com relação à outra célula.

A professora iniciou a aula explicando as funções e explorando as organelas tocando com as mãos. Quando o aluno identificava as organelas dentro da célula ele dizia: "Achei, como está difícil né?" (risos). 
A professora ia pegar na mão dele para passar para próxima organela e ele dizia: "Para, para, para professora que eu já vou achar. O que eu tenho pra falar dessa organela aqui (tocando nos microfilamentos), é que ela está presente apenas na célula animal, e ela lembra uma cobra". Professora: "E o centríolo o que ele te lembra?". Aluno: "Uma cobrinha em cima da outra".

O aluno, ao invés de esperar a professora explicar e falar da próxima organela fazia isso por conta própria. Assim, a professora disse: "Ele não deixa nem a tia explorar" (risos).

Para brincar com o aluno, a professora pediu para ele encontrar a parede da célula animal e ele disse: "Não tem como achar, porque não tem parede, porque isso tem o formato de uma bola como que vai ter parede. Só quem possui parede celular é a vegetal".

Ao terminar de explorar o material com o aluno, a professora disse: "Então você conheceu todas as organelas da célula vegetal e ela tem uma particularidade que a célula animal não tem, que é a parede celular. Você já andou explorando né?". E o aluno respondeu: "Eu já matei toda a charada".

A Fotografia 3 traz exemplos de como a participante explorou o material com seus alunos, e também destaca a legenda das organelas presentes na célula.

Fotografia 3 - Professora utilizando o material para ministrar aula sobre célula animal

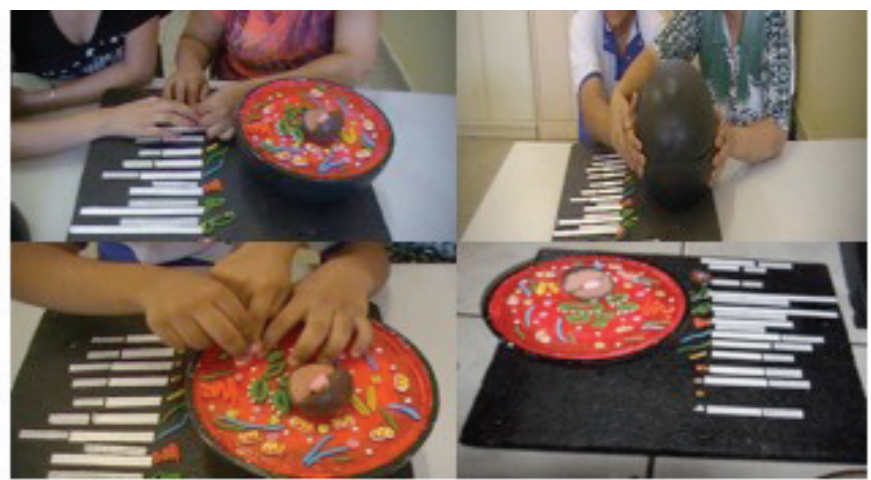

Fonte: Elaborado pelas autoras.

\section{4| DISCUSSÕES}

A visão é de extrema importância, com isso estima-se que a maior parte das informações recebidas por uma pessoa é por meio da visão. Para as pessoas com deficiência visual, as informações transmitidas por outros sentidos também são de importância vital, pois seu mundo é, sobretudo, constituído de diferentes texturas, temperaturas, sons e aromas (CARMO, 2009).

Segundo Uliana (2013), estudos revelam que os estudantes cegos conseguem abstrair informações diversas sobre figuras geométricas e representações gráficas de funções, no mesmo nível que um aluno vidente quando são proporcionados materiais concretos que permitam a utilização do tato.

Dessa forma, assim como na Matemática, visamos na área de Ciências Biológicas, adaptar materiais para uma professora deficiente visual utilizar na sala de recursos com seus alunos, deixando evidente que a participante da pesquisa se sentiu uma profissional mais completa, pois além de saber explorar o material, conseguiu fazer com que seus alunos entendessem o conteúdo, mesmo não sendo professora da área.

Vaz et al. (2012), salienta que os modelos didáticos podem ser considerados como recursos significativos para o ensino de Biologia, devido à possibilidade dos alunos se apropriarem de um 
conceito concreto das estruturas. Além disso, as adaptações realizadas nos materiais possibilitam o uso não somente de alunos videntes, mas também de alunos com deficiência visual.

Com isso, a questão do abstrato sempre foi destacada pela participante da pesquisa ao longo de suas aulas, visto que Célula Animal, Célula Vegetal e Fotossíntese, são conteúdos presentes nos livros apenas na forma de imagens, assim gera-se uma lacuna na aprendizagem tanto da professora quanto dos alunos, e o material fez com que ambos compreendessem esses processos que, até então, eram obscuros.

A partir deste pressuposto, a busca pela construção de recursos que atendam às diferentes características é de extrema importância para a transformação de um ambiente, visando o estabelecimento de uma escola que contribua para a formação crítica de cidadãos, assim, é por meio da construção do conhecimento que os indivíduos passam a ter uma atuação mais significativa na sociedade (VAZ et al., 2012).

Deste modo, consideramos que os objetivos foram alcançados, o material atendeu as necessidades da professora e dos alunos e a mesma destacou sua relevância como apoio para suas aulas.

Entretanto, um ponto merece destaque na fala da professora que é a falta de apoio para que os deficientes exerçam suas funções a contento, pois como ela mesma destaca "[...] minhas prerrogativas como professora é estar buscando um material adaptado para o aluno [...] e eu como professora deficiente visual não tenho essa oportunidade [...]".

Visto que, o Atendimento Educacional Especializado (AEE) fornecido na Sala de recurso multifuncional para os estudantes com deficiência visual, na Resolução CNE n 4 (BRASIL, 2009) e no Decreto $n^{\circ} 7.611$ (BRASIL, 2011) em consonância com a resolução a SE 61 (SÃO PAULO, 2014) apontam aspectos, dos quais trazemos à reflexão:

"Deve ser realizado no contra turno do período que o estudante frequenta, pois a classe comum não substitui o ensino oferecido na sala de aula regular. Deve ser oferecido de forma complementar a formação, como apoio permanente e limitado no tempo e na frequência dos estudantes às salas de recursos multifuncionais." (BRASIL, 2011, 2009).

Isto denota que o AEE, é complementar e não substitutivo à educação comum e deve ocorrer no contraturno ao das aulas regulares, ou seja, no espaço e no tempo destinado ao AEE não é permitido o ensino de conteúdos curriculares, por exemplo, o de Biologia, que deve ocorrer na sala comum com todos os estudantes.

Com isso, Garcia (2013) também afirma que o AEE em salas de recursos na modalidade Educação Especial não é substitutivo ao ensino regular, mas deve apresentar características de complementação e suplementação.

Entretanto, a participante da pesquisa destacou que os alunos pedem que ela tire dúvidas com relação aos conteúdos de Biologia inclusive, pois o aluno fica com lacunas no conhecimento, uma vez que suas necessidades não são supridas no ensino regular. Com isso, a professora relatou em diferentes ocasiões que, muitas vezes, busca compreender conteúdos diversos para auxiliar seus alunos na sala de recursos. Esta situação nos faz refletir sobre a efetividade tanto do ensino regular como do AEE para os alunos com necessidades especiais, gerando questionamentos sobre as responsabilidades com relação ao ensino inclusivo destes alunos. Como destaca Mineiro (2016), em sua pesquisa com professores das salas de recursos no município de Montes Claros - MG, não foram identificadas ações para a capacitação dos professores das salas regulares da Educação Básica, embora seja isso imprescindível para que se efetive a inclusão destes alunos.

Quanto às condições de trabalho das pessoas deficientes, como por exemplo, o relato da participante da pesquisa "[...] e eu como professora deficiente visual não tenho essa oportunidade [...]", destacamos como o mercado de trabalho recebe os deficientes. Bittencourt e Fonseca (2011) 
relatam que as pessoas com deficiência são inseridas no ambiente trabalhista por meio da política de cotas que delimita um percentual de vagas de acordo com porte das empresas. Se de um lado a falta de informações leva a crença de que as pessoas com deficiência não irão atender as expectativas esperadas pela empresa. Por outro lado ainda, questiona-se a adequação do ambiente para que os deficientes tenham plenas condições para exercer suas atividades. Assim sendo, salientamos que a existência de leis, por si só, não garante o acesso e permanência da pessoa deficiente no mercado de trabalho.

\section{5 | CONSIDERAÇÃOS FINAIS}

Como dito anteriormente, consideramos que os objetivos da pesquisa foram alcançados na medida em que os materiais confeccionados atenderam as necessidades da professora e esta, por sua vez, conseguiu utilizá-los de forma adequada como auxílio nas suas aulas.

Entretanto, por meio da análise das falas da professora ao longo do trabalho, observamos que não ocorre uma interação entre o professor do ensino regular e o professor da sala de recursos, sujeito de nossa pesquisa, visto que, perante a lei ambos deveriam trabalhar em conjunto na confecção de materiais adaptados para serem utilizados durante as aulas no ensino regular, e caberia ao professor da sala de recursos o ensino de atividades especificamente suplementares, tais como: o ensino do Braille, do soroban, transcrições de prova de tinta para Braille, de Braille para tinta, etc.

A utilização do material confeccionado para este trabalho, fez com que a professora participante se sentisse com o dever cumprido perante suas aulas, pois ela entende que é sua responsabilidade a complementação dos conteúdos ministrados durante as aulas do ensino regular. Neste sentido, cabe pontuar que a professora cumpriu com o papel que estabeleceu para si, ministrando uma aula completa utilizando corretamente os materiais adaptados e, além da professora, os alunos tiveram a oportunidade de aprender conteúdos que, até então, eram considerados por eles abstratos.

Em suma, a luta de um deficiente visual não se encerra na busca por uma escola que lhe proporcione condições de desenvolver todo o seu potencial. Este cenário vai além, chegando à dificuldade de inserção no mercado de trabalho, por conta da qualificação muitas vezes inadequada, fruto de uma escola deficitária e/ou pela dificuldade no exercício de suas funções trabalhistas devido ao ambiente não preparado para que a inclusão do deficiente seja efetivada. 


\section{REFERÊNCIAS}

ARAUJO, J. P.; SCHMIDT, A. A inclusão de pessoas com necessidades especiais no trabalho: a visão de empresas e de instituições educacionais especiais na cidade de Curitiba. Revista Brasileira de Educação Especial, Marília, v. 12, n. 2, p. 241-254, 2006. Disponível em: <http://www.scielo.br/pdf/rbee/v12n2/a07v12n2>. Acesso em: 10 jun. 2015.

BATISTETIL, C. B. et al. Uma discussão sobre a utilização da história da ciência no ensino da célula para alunos com deficiência visual. In: ENCONTRO NACIONAL DE PESQUISA EM EDUCAÇÃO EM CIÊNCIAS, 7., 2009, Florianópolis. Atas... Florianópolis: ABRAPEC, 2009. p. 1-12. Disponível em: <http://posgrad.fae.ufmg.br/pos-

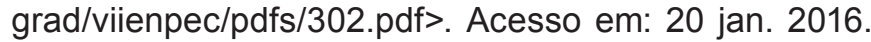

BITTENCOURT, Z. Z. L. C.; FONSECA, A. M. R. Percepções de pessoas com baixa visão sobre seu retorno ao mercado de trabalho. Paidéia, Ribeirão Preto, v. 21, n. 49, p. 187-195, 2011. Disponível em: <http://www.scielo. br/pdf/paideia/v21n49/06.pdf>. Acesso em: 26 set. 2016.

BRASIL. Constituição (1988). Constituição da República Federativa do Brasil. Brasília, DF: Senado Federal, 1988. Disponível em: <http://www.planalto.gov.br/ccivil_03/ constituicao/constituicao.htm>. Acesso em: 09 mar. 2016.

Decreto $n^{\circ} 7.611$, de 17 de novembro de 2011. Dispõe sobre a educação especial, o atendimento educacional especializado e dá outras providências. Diário Oficial da União. Brasília, DF, 18 nov. 2011. Disponível em: <http://www.planalto.gov.br/ccivil_03/_ato20112014/2011/decreto/d7611.htm>. Acessoem:31 dejul. 2015.

Lei $n^{\circ}$ 9.394, de 20 de dezembro de 1996. Estabelece as diretrizes e bases da educação nacional. Diário Oficial da União. Brasília, DF, 23 dez. 1996. Disponível em: <http://www.planalto.gov.br/ccivil_03/leis/ 19394.htm>. Acesso em: 02 mar. 2016.

Ministério da Educação. Secretaria de Educação Especial. Declaração de Salamanca: sobre princípios, políticas e práticas na área das necessidades educativas especiais. Brasília, DF: MEC; Seesp, 1994. 17 p. Disponível em: <http://portal.mec.gov.br/seesp/arquivos/pdf/salamanca.pdf> Acesso em: 09 mar. 2016.

Ministério da Educação. Secretaria de Educação Especial. Programa de capacitação de recursos humanos do ensino fundamental: deficiência visual. Conteúdo: Marilda Moraes Garcia Bruno, Maria Glória Batista da Mota. Colaboração: Instituto Benjamin Constant. Brasília, DF: MEC; Seesp , 2001. 196 p. v. 1. Fasc. I-II-III. (Série Atualidades Pedagógicas; 6), Disponível em: <http://www.dominiopublico.gov.br/download/texto/ me000463.pdf>. Acesso em: 31 jul. 2015.
Resolução CNE/CEB $n^{\circ} 4$, de 2 de outubro de 2009. Institui diretrizes operacionais para o atendimento educacional especializado na educação básica, modalidade educação especial. Diário Oficial da União. Brasília, DF, 5 out. 2009. Seção 1, p. 17. Disponível em: <http://portal.mec.gov.br/dmdocuments/rceb004_09.pdf >. Acesso em: 31 jul. 2015.

CARMO, W. R. Cartografia tátil escolar: experiências com a construção e materiais didáticos e com a formação continuada de professores. 2009. 195 f. Dissertação (Mestrado em Geografia Física) - Faculdade de Filosofia, Letras e Ciências Humanas, Universidade de São Paulo, São Paulo, 2009. Disponível em: $<$ http://www.teses.usp.br/teses/disponiveis/8/8135/tde08032010-124510/pt-br.php>. Acesso em: 26 set. 2016.

ENUMO, S. R. F. Avaliação assistida para crianças com necessidades educacionais especiais: um recurso auxiliar na inclusão escolar. Revista Brasileira de Educação Especial, Marília, v. 11, n. 3, p. 335-254, 2005. Disponível em:<http://www.scielo.br/scielo.php?script=sci arttext\&pid $=\$ 141365382005000300003>$. Acesso em: 16 nov. 2015.

FERREIRA, A. C.; DICKMAN, A. G. História oral: um método para investigar o ensino de física para estudantes cegos. Revista Brasileira de Educação Especial, Marília, v. 21 , n. 2 , p. $245-258,2015$. Disponível em: <http://dx.doi.org/10.1590/S1413-65382115000200006>. Acesso em: 22 dez. 2015.

GARCIA, R. M. C. Política de educação especial na perspectiva inclusiva e a formação docente no Brasil. Revista Brasileira de Educação, Rio de Janeiro, v. 18, n. 52, p. 101-239, 2013. Disponível em: <http://www.scielo. br/pdf/rbedu/v18n52/07.pdf>. Acesso em: 27 set. 2016.

GONSALVES, E. P. Conversas sobre à iniciação da pesquisa científica. Campinas, SP: Editora Alínea, 2001. $79 \mathrm{p}$.

JORGE, V. L. Recursos didáticos no Ensino de Ciências para alunos com deficiência visual no Instituto Benjamin Constant. 2010. 46 f. Monografia (Título em Licenciatura plena em Ciências Biológicas) - Instituto de Biologia, Universidade do Estado do Rio de Janeiro, Rio de Janeiro, 2010. Disponível em: <http://www.decb.uerj.br/arquivos/monografias/MONOGRAGIA_viviane.pdf>. Acesso em: 11 dez. 2015.

LACERDA, C. B. F. A inclusão escolar de alunos surdos: o que dizem alunos, professores e intérpretes sobre esta experiência. Cadernos do CEDES, Campinas, v. 26, n. 69, p. 163-184, 2006. Disponível em: <http://www.scielo.br/pdf/ ccedes/v26n69/a04v2669.pdf>. Acesso em: 25 jul. 2015. 
MAIA, D. P.; MONTEIRO, I. B.; MENEZES, A. P. S. Diferenciando a aprendizagem da biologia no ensino médio, a- través de recursos tecnológicos. In: SEMINÁRIO NACIONAL DE EDUCAÇÃO PROFISSIONAL E TECNOLÓGICA, 1., 2008, Belo Horizonte. Anais... Belo Horizonte: CEFET-MG, 2008. Disponível em: <http://www. senept.cefetmg.br/galerias/Arquivos_senept/anais/terca_tema5/TerxaTema5Poster4.pdf>. Acesso em: 26 set. 2016 .

MANTOAN, M. T. E. Diferenciar para incluir: a educação especial na perspectiva da educação inclusiva. DIVERSA: Educação Inclusiva na Prática, São Paulo, 22 set. 2011. Disponível em: <http://diversa.org.br/artigos/diferenciar-para-incluir-a-educacao-especial-na-perspectiva-da-educacao-inclusiva/>. Acesso em: 26 set. 2016.

MANTOAN, M. T. E.; PRIETRO, A. G. Inclusão escolar: pontos e contrapontos. São Paulo: Summus, 2006. 103 p.

MENDES, E. G. A radicalização do debate sobre inclusão escolar no Brasil. Revista Brasileira de Educação, Rio de Janeiro, v. 11, n. 33, p. 387-559, 2006. Disponível em: <http://www.scielo.br/pdf/rbedu/v11n33/ a02v1133.pdf>. Acesso em: 09 mar. 2016.

MINEIRO, C. C. G. O repensar sobre as dificuldades e inquietudes existentes na educação especial. Cadernos de Pesquisa, São Luís, v. 23, n. 1, 2016. Disponível em: <http://www.periodicoseletronicos.ufma.br/index.php/ cadernosdepesquisa/article/view/4080>Acesso em: 9 mar. 2016.

OLIVEIRA, F. I. W. de; BIZ, V. A.; FREIRE, M. Processo de inclusão de alunos deficientes visuais na rede regular de ensino: confecção e utilização de recursos didáticos adaptados. Marília: Núcleo de Ensino/PROGRAD; Faculdade de Filosofia e Ciências-UNESP, 2002. p. 445-454. Disponível em: <http://www.unesp.br/prograd/PDFNE2003/ Processo\%20de\%20inclusao\%20de\%20alunos $\% 20$ deficientes\%20visuais.pdf>. Acesso em: 11 dez. 2015.

PIRES, B. B. M.; JORGE, V. L. Confecção de modelos biológicos para alunos cegos no segundo segmento. In: SEMINÁRIO INTERNACIONAL DE INCLUSÃO ESCOLAR: PRÁTICAS EM DIÁLOGO, 1., 2014, Rio de Janeiro. Anais... Rio de Janeiro: UERJ, 2014. p. 1-5. Disponível em: <http://www.cap.uerj.br/site/images/stories/ noticias/2-pires_e_jorge.pdf>. Acesso em: 20 jan. 2016.

PLETSCH, M. D. A formação de professores para a educação inclusiva: legislação, diretrizes políticas e resultados de pesquisas. Educar em Revista, Curitiba, n. 33, p. 143-156, 2009. Disponível em: <http://www.scielo. br/scielo.php?pid=S0104-40602009000100010\&scri pt=sci_arttext>. Acesso em: 22 maio 2014.
SANT'ANA, I. M. Educação inclusiva: concepções de professores e diretores. Psicologia em Estudo, Maringá, v. 10, n. 2, p. 227-234, 2005. Disponível em: <http:// www.scielo.br/pdf/pe/v10n2/v10n2a09.pdf>. Acesso em: 17 jul. 2015.

SÃO PAULO. Secretaria da Educação. Resolução SE n ${ }^{\circ}$ 61, de 11 de novembro de 2014. Dispõe sobre a Educação Especial nas unidades escolares da rede estadual de ensino. 2014. Disponível em: <http://siau.edunet.sp.gov. br/ItemLise/arquivos/61_14.HTM?Time=09/07/2015\%20 13:44:19>. Acesso em: 10 jul. 2015.

SILVA, L. M. Educação Inclusiva e formação de professores. 2009. 90 f. Monografia (Especialização Latu Sensu a distância em Educação Profissional Tecnológica Inclusiva) - Instituto Federal de Educação, Ciência e Tecnologia do Estado do Mato Grosso, Cuiabá, 2009. Disponível em: <http://bento.ifrs.edu.br/site/midias/arquivos/2010069353641lidia_monografia.pdf>. Acesso em: 22 maio 2015.

ULIANA, M. R. Inclusão de estudantes cegos nas aulas de matemática: a construção de um kit pedagógico. Bolema, Rio Claro, v. 27, n. 46, p. 597-612, 2013. Disponível em: <http://www.scielo.br/pdf/bolema/v27n46/ v27n46a17.pdf>. Acesso em: 16 nov. 2015.

VAZ, J. M. C. et al. Material didático para ensino de biologia: possibilidades de inclusão. Revista Brasileira de Pesquisa em Educação em Ciências, v. 12, n. 3, p. 81104, 2012. Disponível em: <https://seer.ufmg.br/index. php/rbpec/article/view/2447/1847>. Acesso em: 16 nov. 2015.

\section{Agradecimento}

Ao Prof. Dr. Eder Pires de Camargo por ceder o Laboratório de Pesquisa e Estudos em Ensino de Ciências e Inclusão Escolar (LEPENCINE) para a impressão dos conteúdos em Braille utilizados no trabalho e por ter sempre se colocado à disposição para nos auxiliar. 